\title{
Educating Future Physicians for Ontario and the physicians' strike of 1986: the roots of Canadian competency-based medical education
}

- Cite as: CMAJ 2018 February 20;190:E196-8. doi: 10.1503/cmaj.171043

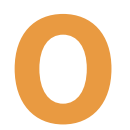

n June 12, 1986, Ontario physicians walked out on strike to protest the province's imminent ban on extra-billing. The ban originated in 1980 when Justice Emmett Hall recommended making extra-billing illegal because it reduced access to care for poorer patients. In 1984, the federal government unanimously passed the Canada Health Act, which required provinces to meet certain principles in order to receive transfer payments for health care; one principle was the abolition of extra-billing.

Extra-billing was defined by University of Ottawa health economist Pranlal Manga as, "any point of service charges higher than the provincial benefit schedule that patients were required to pay for insured medical services." It involved "an out-ofpocket cost to the patient for the use of medical services and a transfer of the sum to the physician providing the service." ${ }^{1}$ The public opposed the practice, but until the enactment of the act, physicians could extra-bill whether they opted in or out of provincial insurance plans.

Starting July 1,1984 , the federal government would penalize provinces by withholding its payments by one dollar for each dollar extra-billed. Provinces could recover these monies, without interest, if they banned extra-billing by Apr. 1, 1987. Provinces continuing to permit extra-billing would lose the right to recover withheld funds. This threat, coupled with widespread public opposition to extra-billing, compelled the provinces to comply.

Most provinces passed legislation banning extra-billing despite resistance from some medical associations. However, in Ontario, the story was different: physicians' resistance to Bill 94, the Health Care

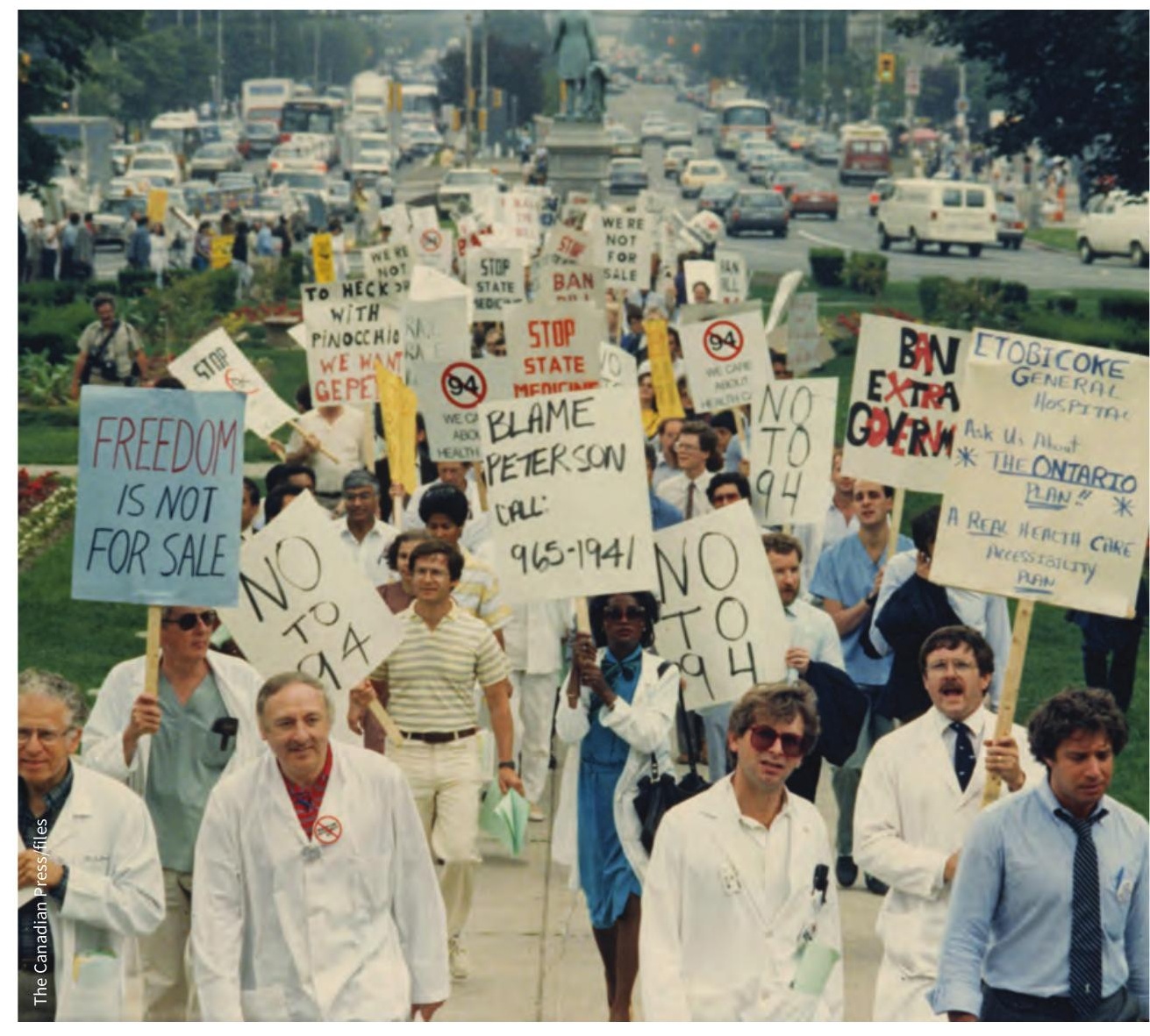

Ontario physicians march on Queen's Park in Toronto, Ont., June 15, 1986, during their strike to protest a government ban on extra-billing.

Accessibility Act, culminated in the longest physicians' strike in Canadian history.

Two factors prompted the response. First, although other provinces had larger proportions of physicians who were extrabilling, physicians in Ontario charged the greatest amount, an estimated $69.7 \%$ (\$49 million) of the national total of extrabilled funds. Although only $12 \%$ of Ontario physicians had opted out (and could extra-bill), physicians who opted in found ways to extra-bill by selectively opting certain patients out and charging them directly. Second, although extrabilling was most prevalent within highearning specialties - anesthesia (58.3\%), ophthalmology (39.5\%), urology (37.6\%), and obstetrics and gynecology (33.8\%) family practitioners decided to support the strike when the Ontario Medical Association agreed to address the increasing income disparity between specialties. "If 
[Ontario Medical Association negotiators] don't give us their support [to correct] the disparity of incomes, they're really not going to have family practice to rely on in any struggle with the government," said Dr. Tim Kerr, a family practitioner and member of the Ontario Medical Association executive. ${ }^{2}$ Thus, for the first time, family practitioners enjoyed equal representation on the Ontario Medical Association's Tariff Committee, and physicians formed a front against the government.

The physicians contended that the right to extra-bill served to safeguard physician autonomy; it had become a tradition, originating as a hard-won concession to Saskatchewan physicians during their 1962 strike. Bill 94 eliminated the Ontario physicians' option to practise independently. According to the striking physicians, it infringed on their rights and autonomy and would allow unwelcomed government interference in the physicianpatient relationship, thereby threatening health care. Dr. William Vail, President of the Ontario Medical Association, stated, "We can hear the wolves howling. Bill 94 is perceived as a very serious threat to the physician's professional freedom, as a threat to the physician's ability to serve as a completely independent advocate for the patient and as a threat to the physician's ultimate ethical responsibility." 3 Dr. William Goodman, leader of a group of about 1500 physicians who had opted out, believed that the ban was reminiscent of the all-too-familiar totalitarian scourges on both sides of the political spectrum: "In the extreme ... [the ban] leads to state doctors like the notorious [Joseph] Mengele of the Nazi concentration camps and like the state psychiatrists in Russian political prisons."

By June 12, the federal government had withheld $\$ 100$ million dollars in penalties from Ontario, and neither physicians nor the province were willing to budge from their entrenched positions. The Ontario Medical Association estimated that $50 \%$ to $60 \%$ of physicians went on strike; however, billing data from that period suggest that fewer physicians had participated.

Frequent discrepancies arose between data reported by the Ontario Medical Association and data reported by the media. During the strike, clinics and emergency wards were closed, and appointments and surgeries were cancelled. Reports of patient maltreatment littered the newspapers. "Hospital turns away bleeding tot," read one front-page carious patient. ${ }^{6}$ Newspapers, churches, universities, nurses, interest groups, ethicists and business criticized the physicians' actions, which, according to the head of the Ontario Public Health Association, were "disgusting and unethical."

\section{"In public opinion, the withdrawal of services was not motivated by noble ideals of autonomy or quality of care; instead, the physicians' motives were seen as selfish, predatory and duplicitous."}

headline. ${ }^{5}$ Newspapers printed advice for what to do when people needed medical care, and they published maps showing which emergency departments remained open. Physicians at York County Hospital in Newmarket, Ont., passed a motion to withdraw "all" services, even in lifethreatening situations. The Ontario Medical Association condoned, as "protest strategy," the closure of intensive care units and entire hospitals. Patients waiting in emergency departments described anger, resignation and fear.

Once Bill 94 passed on July 5, physicians devised new charges, including "guaranteed appointment fees" levied in lieu of extra-billing. The strike ended on July 7 , but it continued at select hospitals until September, when the Ontario Medical Association agreed to participate in open talks.

Striking physicians obtained little public support. Extra-billing was already unpopular, and strike tactics did more damage. In public opinion, the withdrawal of services was not motivated by noble ideals of autonomy or quality of care; instead, the physicians' motives were seen as selfish, predatory and duplicitous. "It's not about the money, it's about the principle of the money," wrote The Toronto Star, lampooning the Ontario Medical Association as a greedy vulture preying on a pre-
Beyond failing to achieve its stated objective - preserving the right to extrabill - the strike was a major public-relations disaster for Ontario's physicians. In the words of Ontario Medical Association President Dr. Richard Railton, the profession's "place in society has changed. After the strike, some people will be disillusioned and disappointed especially those who have put doctors on an impossible pedestal. I think that doctors will later return to being a highly regarded group in society but may not be put on an unnaturally high pedestal they shouldn't be there anyway."

Bioethicist Dr. Eric Meslin identified the "moral costs" of the Ontario strike, but the damage to professional reputation came at a time when medicine was confronting social criticism in other developed countries (Appendix 1, available at www.cmaj.ca/lookup/suppl/doi:10.1503/ cmaj.171043/-/DC1). In an oft-cited article, historian Dr. Rosemary A. Stevens argued that by 1990 a sharp decline in the professional reputation of physicians had occurred in the United States from its peak in 1960. She identified its source as the failure of Congress to adopt universal health care and the ensuing market forces that pitted doctors against government and patients. ${ }^{9}$ This situation created a sense of urgency that demanded a response from medical educators everywhere. 
It was in this atmosphere in 1988 that Dr. Donald Wilson, president of the Ontario-based philanthropic organization Associated Medical Services (AMS), decided to act: "[Donald Wilson] was deeply concerned about the apparent diathesis between the profession and the community ... he felt that AMS should undertake an educational project that attempted to close the gap and bring the profession closer to the community it served." 10 He observed that "the doctors looked like money-grubbers ... they came out of [the strike] looking poorly and without much sympathy from people." ${ }^{\text {11 }}$ Family physician and future medical dean of the University of Manitoba, Dr. Brian Hennen, was also involved in the initiative and said that the "EFPO [Educating Future Physicans for Ontario] project was really a response to the '80s doctors' strike."12

Thus began a process through which leaders of Educating Future Physicians for Ontario sought to make medical education, as Neufeld and colleagues noted, "more responsive to the evolving needs of the Ontario society." ${ }^{13}$ In focus groups held with educators and local citizens in communities across Ontario, Educating Future Physicians for Ontario found that people wanted the physician to fill several roles: scientist-scholar, learner, communicator, health advocate, collaborator, gatekeeper and person. It is interesting that in her study of the decline of physician reputation in the US, Rosemary Stevens outlined most of the same competencies as challenges for American medical educators. ${ }^{9}$

Results of the consultations were discussed by medical educators who then devised strategies to develop these roles in curriculum. With Associated Medical Services and government support, Educating Future Physicians for Ontario fostered a conversation between the five medical schools in Ontario and beyond. It engaged libraries, students and residents with fellowships, research grants and other learning opportunities, including conferences, and featured dialogue between the profession and the public. Launched in 1990, the energetic activity continued through two phases until December 1998. Among the youthful participants in this provincial work was Jason R. Frank, then a medical student at the University of Ottawa.

These roles in Educating Future Physicians for Ontario "went national" through the Royal College of Physicians and Surgeons of Canada, of which Wilson was president from 1988 to 1990.

By 1996, the roles in Educating Future Physicians for Ontario had been revised and incorporated into the influential CanMEDS competency framework, which is used across Canada and beyond. Many authors have recorded this history (Appendix 1). However, the impact of these pervasive changes on medical professionalism and reputation have yet to be measured.

Dr. Jason R. Frank, now an emergency medicine specialist with expertise in education, is the Director of Specialty Education, Strategy, and Standards at the Royal College's Office of Specialty Education. In that capacity, he is a leader in the CanMEDS competency movement.

Dr. Wilson died on Jan. 4, 2017, but his legacy lives on in the Wilson Centre at the University of Toronto, the Wilson Fellowship and the Royal College/Associated Medical Services Donald R. Wilson Award, which has recognized the accomplishments of those who integrate CanMEDS competencies in medical education since 2004.

These changes began in a response to the Ontario physicians' strike of 1986.

\section{Hissan Butt BA \\ Jacalyn Duffin MD PhD}

School of Medicine, Queen's University, Kingston, Ont.

\section{References}

1. Manga P. The political economy of extra-billing. Ottawa: University of Ottawa; 1983. Available: https://ruor.uottawa.ca/handle/10393/19055 (accessed 2018 Jan. 31).

2. McQuaig L. Deal on income gap united OMA members in extra-billing protest. The Globe and Mail [Toronto] 1986 Mar. 5;A1.

3. Remarks from March 25, 1986, cited in Taylor M. Health insurance and Canadian public policy: the seven decisions that created the Canadian health insurance system and their outcomes. Montréal: McGill-Queen's University Press; 2009:455.

4. Harrington D. Two doctors vow to defy any ban on extra-billing. Toronto Star 1986 Mar. 19;A13.

5. Ferguson J. Hospital turns away bleeding tot. Toronto Star 1986 June 14;A1,12.

6. Laughter is the best medicine. Toronto Star 1986 June 9;A16.

7. Flavelle D. Strike "disgusting" health group charges. Toronto Star 1986 June 26;A10.

8. Douglas J. Leader of the OMA has no regrets. The Globe and Mail [Toronto] 1986 July 7;A10.

9. Stevens RA. Themes in the history of medical professionalism. Mt Sinai J Med 2002;69:357-62.

10. Seidelman W. Remembring Dr. Donald Wilson. Toronto: Associated Medical Services; 2017. Available: http://www.ams-inc.on.ca/remembering-dr-donald-wilson/ (accessed 2017 Aug. 25).

11. Crawford T. Trainee doctors put caring above all else. Mt Sinai J Med 1993 Dec. 4;A1,A8.

12. Study of doctor's role model becomes model (Educating Future Physicians for Ontario). Medical Post 1996 June 11;32:22-43.

13. Neufeld VR, Maudsley RF, Pickering RJ, et al. Educating future physicians for Ontario. Acad Med 1998;73:1133-48.

This article has been peer reviewed. 